\title{
Peningkatan Kemampuan Pemecahan Masalah Matematika melalui Model Pembelajaran Berbasis HOTS
}

\author{
Erna Sari Agusta \\ Madrasah Tsanawiyah Negeri 28 Jakarta, Cakung, Jakarta Timur \\ Email: ernasari.agusta@gmail.com
}

\begin{abstract}
Abstrak
Titik sentral yang harus dicapai dalam kegiatan belajar mengajar adalah tercapainya tujuan pembelajaran. Guru diharuskan mendesain pembelajaran dengan berbagai metode denga $\mathrm{n}$ diselipka $\mathrm{n}$ beberapa permasalahan yang dapat merangsang da ya nalar siswa (materi harus ditingkatkan sampai analisis dan sintesis). Penelitian ini berdasarkan permasalahan : Bagaimana pengaruh model pembelajaran berbasis HOTs terhadap kemampuan pemecahan masalah matematika?. Sedangkan tujuan dari penelitian ini adalah ingin mengetahui peningkatan kemampuan pemecahan masalah matematika siswa setelah diterapkannya model pembelajaran berbasis HOTs. Penelitian ini adalah penelitian action research sebanyak 2 siklus, dimana setiap siklusnya terdiri dari rancangan, pelaksanaan, refleksi, dan revisi. Sasaran penelitian ini adalah siswa kelas VII-2 MTsN 28 Jakarta. Data diperoleh dari angket aktifitas siswa, hasil tes formatif, dan lembar observasi kegiatan. Dari hasil analisis didapatkan bahwa hasil belajar siswa mengalami peningkatan dari siklus I sampai siklus III yaitu, 44,4\% (siklus I), 69,4\% (siklus II), 80,5\% (siklus III). Simpulan dari penelitian ini adalah penerapan model pembelajaran berbasis HOTs dapat berpengaruh positif terhadap kemampuan pemecahan masalah siswa kelas VII-2 MTsN 28 Jakarta.
\end{abstract}

Kata kunci : pembelajaran matematika, kemampuan pemecahan masalah, metode problem solving.

\section{PENDAHULUAN}

Bagi sebagian peserta didik di MTsN 28 Jakarta, matematika adalah salah satu mata pelajaran yang dianggap cukup sulit karena soal-soal yang disajikan umumnya adalah soal pemecahan masalah. Kesulitan mereka antara lain disebabkan oleh keterbatasan dalam memahami soal yang diberikan serta menentukan bentuk penyelesaiannya. Hal ini disebabkan oleh kurangnya guru dalam memfasilitasi proses belajar yang dapat merangsang keterampilan berpikir tingkat tinggi. Fakta ini didukung oleh hasil penilaian harian peserta didik yang kurang dari $75 \%$ ketuntasan secara k la sikal . Kecenderungan siswa untuk menghafal beberapa rumus daripada memahami dan menerapkan rumus merupakan hal yang sudah menutup berkembangnya kemampuan pemecahan masalah peserta didik untuk menyelesaikan soal-soal kemampuan pemecahan masalah.

Adapun fakta lain dari rendahnya kemampuan pemecahan masalah ini adalah kurang mandiriny a peserta didik dalam mengerjakan latihan atau tugas. Peserta didik hanya mampu untuk menyelesaikan masalah berdasarkan contoh soal yang diberikan. Jika soal latihan atau tugas disajikan dalam bentuk lain maka peserta didik akan mengalami kesulitan dalam menyelesaikannya. Rendahnya kemampuan pemecahan masalah ini dapat dilihat dari hasil an alisis penilaian harian peserta didik sebelum dilakukan tindakan seperti dalam tabel dibawah ini: 
TABEL 1. Tabel Penguasaan Indikator Kemampuan Pemecahan Masalah

\begin{tabular}{|c|l|c|c|}
\hline No & \multicolumn{1}{|c|}{ Indikator Pemecahan Masalah } & $\begin{array}{c}\text { Jumlah Siswa yang } \\
\text { Menguasai Indiktor }\end{array}$ & Prosentase \\
\hline 1. & Memahami masalah & 16 & $50 \%$ \\
\hline 2. & Merencanakan penyelesaian & 13 & $40,625 \%$ \\
\hline 3. & Menyelesaikan masalah sesuai rencana & 12 & $37,5 \%$ \\
\hline 4. & $\begin{array}{l}\text { Melakukan pengecekan kembali terhadap } \\
\text { hasil yang diperoleh }\end{array}$ & 11 & $34,375 \%$ \\
\hline
\end{tabular}

Berdasarkan data diatas, dapat diketahui bahwa indikator utama yang menentuk an ke ma mpuan pemecahan masalah adalah memahami masalah yang disajikan. Jika peserta didik memahami masalah maka mereka dapat merencanakan dan menyelesaikan masalah serta dapat mengecek kembali hasil yang telah diperoleh.

Materi Luas dan Keliling Bangun Datar adalah pokok bahasan yang menuntut banyak pemikiran yang diawali dengan proses penemuan sebuah rumus lalu menerapkann ya dalam menyelesaikan permasalahan sehari-hari. Kesulitan yang banyak dialami peserta didik umumnya disebabkan oleh kurangnya kemampuan awal sehingga mereka tidak paham tentang bentuk dan rumus y ang dipakai dalam memecahkan masalah yang berhubungan dengan materi Luas dan Keliling Bangun Datar. Selain itu, model pembelajaran yang diterapkan masih bersifat konvensional dan teacher oriented dimana siswa hanya belajar dari contoh-contoh soal yang diberikan oleh guru sehingga mereka tidak dapat membangun sendiri pengetahuannya.

Menurut Saad \& Ghani (2008), kemampuan pemecahan masalah adalah kemampuan untuk merencanakan yang harus dilakukan supaya mendapatkan penyelesaian tertentu dari sebuah masalah yang mungkin tidak didapat dengan segera. Polya (1973) mendefinisikan bahwa pemecahan masalah sebagai usaha mencari jalan keluar dari suatu kesulitan. Kemampuan pemecahan masalah merupakan salah satu aspek dalam berpikir tingkat tinggi. G.Polya (1973) dalam bukunya "How to Solve It" menyatakan bahwa kemampuan pemecahan masalah merupakan suatu tingkat aktivitas intelektual yang sangat tinggi, yaitu aktivitas untuk mencari pen yelesaian masalah yang dihadapi dengan menggunakan berbagai bekal pengetahuan yang sudah dimiliki.

Menurut penelitian yang dilakukan Hidayati (2017) kemampuan pemecahan masalah merupak an tujuan umum dalam pembelajaran matematika, bahkan sebagai jantungnya matematika, artinya kemampuan pemecahan masalah merupakan kemampuan dasar dalam matematika. Sumarno dan Hendriana (2014) mengatakan bahwa kemampuan pemecahan masalah adalah kemampu an untuk berpikir analitik dalam mengambil keputusan dalam kehidupan sehari-hari dan kemampuan berpikir kritis dalam menghadapi situasi yang baru. Berdasarkan beberapa pendapat diatas dapat dikatakan bahwa kemampuan pemecahan masalah adalah kemampuan memecahkan masalah matematika dengan menggunakan pemahaman sebelumnya atau kajian-kajian yang relevan secara logis dan teliti untuk menyelesaikan masalah dan menghadapi situasi yang tidak rutin.

G.Polya (1973) dalam bukunya yang berjudul "How to Solve It" juga merinci beberapa empat tahapan pemecahan masalah beserta pertanyaan yang yang sering digunakan sebagai indikator un tuk masing-masing tahapan sebagai berikut:

(1) Memahami Masalah

Kemampuan ini meliputi pemberian label dan pengidentifikasian tentang apa yang ditanyakan, syarat-syarat apa yang diketahui datanya, dan menentukan solusi masalahnya. Siswa tidak mungkin dapat menyelesaikan masalah dengan benar, jika tidak memahami masalah yang diberikan. Indikator untuk tahapan pertama ini adalah ketika siswa mampu menunjukkan bagian-bagian prinsip dari masalah, yang ditanyakan, yang diketahui, dan prasyarat.

(2) Merencanakan Pemecahan Masalah

Kemampuan ini akan sangat bergantung pada pengalaman peserta didik dalam menyeles aikan masalah. Semakin bervariasi pengalaman siswa maka mereka akan semakin kreatif menyusun rencana penyelesaian masalah. Indikator dari kemampuan ini adalah ketika siswa mampu menghubungkan sesuatu dengan permasalahan yang diberikan, lalu mereka dapat menyatakan 
kembali permasalahan tersebut sehingga muncul gagasan cemerlang yang bersumber dari pengalaman atau pengetahuan sebelumnya.

(3) Menyelesaikan Masalah Sesuai Rencana

Pada kemampuan ini, siswa harus benar-benar mengerti dengan gagasan yang telah direncanakan. Indikator dari tahapan ini adalah ketika peserta didik men yakini kebenaran setiap langkah penyelesaian yang telah ditetapkan sebelumnya.

(4) Memeriksa Kembali Hasil yang Diperoleh

Pada kemampuan ini, siswa akan menuliskan hasil yang diperoleh dengan baik dan rapi. Gu ru dapat mengetahui kemampuan ini dengan cara menukarkan jawaban antar peserta didik. In dikator untuk tahapan ini adalah ketika siswa mampu memeriksa kembali jawaban temannya, me mberikan argumen terhadap jawaban tersebut dan dapat menemukan ja wab an temanny a dengan cara yang berbeda(Windari, 2014)

Sedangkan menurut Shadiq (2014) ada empat indikator kemampuan pemecahan masalah y aitu: memahami masalahnya, merancang cara penyelesaiannya, melaksanakan rencananya, dan menaf sirkan hasilnya. Berdasarkan dua pendapat tersebut maka dapat dikatakan bah wa siswa yang menguasai kemampuan pemecahan masalah adalah mereka yang dapat memahami masalah, merencanakan pemecahannya, melaksanakan pemecahan masalahnya sesuai rencana, dan mengecek kembali solusi dari permasalshan tersebut.

Pengembangan pembelajaran yang berorientasi pada keterampilan berpikir tingkat tinggi atau Higher Order Thinking Skill (HOTs) merupakan upaya pemerintah dalam peningkatan kualitas pembelajaran dan kualitas lulusan. Hal tersebut sesuai dengan tujuan pembelajaran matematika menurut Kemdikbud (2013) yaitu (1) meningkatkan kemampuan intelektual, khususnya kemampuan tingkat tinggi siswa; (2) membentuk kemampuan siswa dalam menyelesaikan suatu mas alah secara sistematis; (3) memperoleh hasil belajar yang tinggi; (4) melatih siswa dalam mengk omu nikasikan ide-ide, khususnya dalam menulis karya ilmiah; (5) mengembangkan karakter siswa. Program ini dikembangkan mengikuti arah kebijakan Kementerian Pendidikan dan Kebudayaan tahun 2018 y ang terintegrasi dengan penguatan pendidikan karakter dan pembelajaran yang berorientasi pada keterampilan tingkat tinggi.

Implementasi Kurikulum 2013 menurut Permendikbud No. 22 Tahun 2016 tentang Standar Proses merekomendasikan tiga model pembelajaran yang dapat meningkatkan kemampuan pemecahan masalah, berorientasi pada perilaku saintifik, sosial, pengembangan rasa keingin tahuan dan berbasis HOTs yaitu:

(1) Model Pembelajaran Berbasis Masalah

Menurut Trianto (2016) model pembelajaran berbasis masalah adalah pembelajaran yang menyajikan kepada siswa situasi masalah yang autentik dan bermakna yang dapat memberikan kemudahan kepada mereka untuk melakukan peyelidikan dan inquiry. Pengajaran berdasarkan masalah merupakan pendekatan yang efektif untuk pengajaran proses berpikir tingkat tinggi. Model pembelajaran ini membantu siswa untuk memproses informasi yang sudah jadi dalam benaknya dan menyusun pengetahuan mereka sendiri tentang dunia sosial dan sekitarn ya. Menurut Ratumanan (dalam Trianto, 2016) model pembelajaran berbasis masalah ini pun cocok untuk menge mban gkan pengetahuan dasar maupun kompleks. Menurut Arends (dalam Trianto, 2016) pengajaran berdasarkan masalah merupakan suatu pendekatan pembelajaran dimana siswa mengerjakan permasalahan yang autentik dengan maksud untuk menyusun pengetahuan mereka sendiri, mengembangkan inquiri dan keterampilan berpikir tingkat tinggi, mengembangkan kemandirian dan percaya diri.

\section{(2) Model Pembelajaran Berbasis Proyek (Project Based Learning)}

Menurut Joel L Klein et.al ( dalam Widyantini, 2014) menjelaskan bahwa pembelajaran berbasis proyek adalah strategi pembelajaran yang memberdayakan siswa untuk memperoleh pengetahuan dan pemahaman baru berdasarkan pengalamannya melalui berbagai presentasi. Model pembelajaran berbasis proyek menurut Buck Institute for Education (dalam M. Hosnan, 2014) merupakan suatu model pembelajaran sistematis yang melibatkan siswa dalam belajar ilmu pengetahuan dan keterampilan melalui proses penyelidikan terhadap masalah-masalah nyata dan pembuatan berbagai karya yang dirancang secara hati-hati. Sedangkan menurut Ridwan Abdullah Sani (2016) model 
pembelajaran berbasis proyek adalah model pembelajaran yang melibatkan siswa untuk mengerjakan sebuah proyek yang bermanfaat untuk menyelesaikan permasalahan mas yarakat atau lingkungan.

Berdasarkan pendapat para ahli diatas maka dapat dikatakan model pembelajaran berbasis proyek merupakan suatu model pembelajaran yang menyangkut pemusatan pertanyaan dan masalah bermakna, pemecahan masalah, pengambilan keputusan, proses pencarian berbagai sumber, pemberian kesempatan kepada anggota unuk bekerja secara kolaborasi, dan menutup dengan presentasi produk nyata.

(3) Model Pembelajaran Penyingkapan/Penemuan (Discovery Learning)

Anitah (dalam Gina, 2016) menyatakan bahwa belajar penemuan atau discovery learning merupakan suatu pembelajaran yang melibatkan siswa dalam pemecahan masalah untuk pengembangan pengetahuan dan keterampilan. Menurut Ilahi (dalam Gina, 2016), model pembelajaran discovery learning merupakan model pembelajaran yang menggunakan kegiatan dan pengalaman langsung sehingga akan lebih menarik perhatian anak didik dan memungkinkan pembentukan konsep-konsep abstrak yang mempunyai makna, serta kegiatannya pun lebih realistis.

Model belajar penemuan menurut Bruner (dalam Sudjana, 2014) adalah kegiatan penemuan yang dilakukan oleh manusia itu sendiri dan dilakukan secara aktif akan memberikan hasil yang lebih baik, serta akan bermakna bagi dirinya sendiri. Suryobroto (2009) menambah kan jika siswa dilibatkan secara terus menerus dalam pembelajaran penemuan maka siswa tersebut akan lebih memahami dan mampu mengembangkan aspek kognitif yang dimilikinya. Melalui Model Discovery Learning sis wa menjadi lebih dekat dengan apa yang menjadi sumber belajarnya, rasa percaya diri siswa pun akan meningkat karena dia merasa apa yang telah dipahaminya ditemukan oleh dirinya sendiri. Kerjasama dengan temannya akan lebih meningkat, serta tentunya dapat menambah pengalaman siswa.

Berdasarkan beberapa pendapat di atas dapat disimpulkan bahwa model pembelajaran discovery learning adalah pembelajaran yang melibatkan siswa untuk menemukan sendiri suatu konsep dari materi tertentu, yang dilakukan secara aktif dan terus menerus, sehingga berkembang aspek kognitifnya.

Berhubungan dengan model pembelajaran berbasis HOTs, maka penulis telah melakukan penelitian tindakan kelas dengan fokus penelitian: (1) Apakah model pembelajaran berbasis HOTs dapat meningkatkan kemampuan pemecahan masalah matematika siswa?; (2) Bagaimana penerapan model pembelajaran berbasis HOTs dalam meningkatkan kemampuan pemecahan masalah matematika siswa?. Adapun tujuan dari penelitian ini adalah: (1) Meningkatnya kemampuan pemecahan masalah matematika yang berdampak pada peningkatan hasil belajar siswa, (2) Menerapkan model pembelajaran berbasis HOTs dengan baik. Sedangkan manfaat dari penelitian ini adalah: (1) Sebagai bahan referensi dan rujukan bagi dewan guru pada umumnya dan para guru matematika pada khususnya di MTsN 28 dalam memperkaya ide dan kreativitas dalam model pembelajaran; (3) Dengan hasil belajar yang meningkat maka dapat meningkatk an kualitas output sekarang dan yang akan datang.

\section{METODE}

Penelitian tindakan kelas ini dilaksanakan di kelas VII-2 MTsN 28 Jakarta yang terdiri dari 36 siswa. Penelitian dilaksanakan dari bulan Agustus sampai November 2018. Sebagai data awal, peneliti menggunakan nilai siswa pada tahun sebelumnya. Penelitian ini dilaksanakan dalam 3 siklus, yang masing-masing siklus terdiri dari tahapan perencanaan, pelaksanaan tindakan, observasi, evaluasi, dan refleksi. Adapun kegiatan tiap siklusnya dimulai dengan mengadakan perte muan guru pelaksana tindakan dan guru pengamat untuk mendiskusikan persiapan penelitian. Teknik pengumpulan data yang digunakan adalah angket respon peserta didik, soal tes, pedoman wawancara dan catatan lapangan,

Pada tahap pelaksanaan tindakan, guru matematika kelas VII-2 sebagai pelaksana tindakan melaksanakan kegiatan pembelajaran sesuai dengan rencana pembelajaran yang telah disusun. Dalam waktu yang sama observasi terhadap guru pelaksana pun dilakukan oleh guru pengamat. Untuk mengukur kemampuan pemecahan masalah, instrumen yang digunakan adalah tes. Sedangkan untuk mengevaluasi aktivitas peserta didik di kelas menggunakan observasi dan wawancara. Disamping itu 
untuk mengetahui respon siswa terhadap model pembelajaran berbasis HOTs maka digunakan angket respon siswa.

Pada tahap refleksi, data yang diperoleh dari hasil evaluasi kemudian dianalisis. Hasil analisis digunakan untuk merefleksi tindakan pada siklus tersebut. Hasil refleksi kemudian digunakan untuk membuat perencanaan tindakan pada siklus berikutnya. Penelitian dihentikan jika sudah terdapat peningkatan hasil belajar pada siswa pada masing-masing subjek penelitian.

\section{HASIL DAN PEMBAHASAN}

Berdasarkan analisis data, dapat diketahui bahwa kemampuan pemecahan masalah matematika peserta didik dalam belajar dari siklus I sampai siklus III mengalami peningkatan. Peserta didik telah terlihat beberapa peserta didik yang bersemangat untuk belajar matematika. Berdasarkan hasil wawancara diketahui beberapa peserta didik telah menganggap matematika sebagai mata pelajaran yang mudah dan menarik. Oleh karena itu, banyak peserta didik yang merasa tertantang untuk mengerjakan tugas-tugas yang diberikan oleh guru. Hal ini dapat dilihat dari penngkatan jumlah peserta didik yang menguasai indikator kemampuan pemecahan masalah.

TABEL 2. Rekapitulasi Penguasaan Indikator Kemampuan Pemecahan Masalah

\begin{tabular}{|l|c|c|c|}
\hline \multicolumn{1}{|c|}{$\begin{array}{c}\text { Indikator Kemampuan Pemecahan } \\
\text { Masalah }\end{array}$} & Siklus I & Siklus II & Siklus III \\
\hline Memahami masalah & $\begin{array}{c}21 \text { orang } \\
(58,3 \%)\end{array}$ & $\begin{array}{c}25 \text { orang } \\
(69,4 \%)\end{array}$ & $\begin{array}{c}29 \text { orang } \\
(80,5 \%)\end{array}$ \\
\hline Merencanakan pemecahan masalah & 18 orang (50\%) & $\begin{array}{c}25 \text { orang } \\
(69,4 \%)\end{array}$ & $\begin{array}{c}28 \text { orang } \\
(77,7 \%)\end{array}$ \\
\hline Menyelesaikan masalah sesuai rencana & 18 orang (50\%) & $\begin{array}{c}25 \text { orang } \\
(69,4 \%)\end{array}$ & $\begin{array}{c}28 \text { orang } \\
(77,7 \%)\end{array}$ \\
\hline Memeriksa kembali hasil yang diperolah & $\begin{array}{c}16 \text { orang } \\
(44,4 \%)\end{array}$ & $\begin{array}{c}24 \text { orang } \\
(66,7 \%)\end{array}$ & 27 orang (75\%) \\
\hline
\end{tabular}

Pada siklus I terlihat adanya peningkatan jumlah peserta didik yang menguasai setiap indikator pemecahan masalah. Pada siklus I, 58,3\% peserta didik sudah dapat memahami masalah, tapi dalam merencanakan, menyelesaikan, dan memeriksa kembali hasil yang diperoleh masih kurang dari 50\% . Pada siklus II diketahui bahwa 69,4\% peserta didik sudah dapat memahami masalah, meren canakan dan menyelesaikan masalah sesuai rencana. Sedangkan pada siklus III, penguasaan setiap in dikator secara klasikal sudah mencapai minimal $75 \%$

Rendahnya penguasaan indikator pada siklus I disebabkan oleh kurangnya pengetahu an awal mereka tentang operasi perkalian dan pembagian pada bilangan. Pengetahuan awal matematika adalah pengetahuan yang dimiliki siswa sebelum proses pembelajaran berlangsung. Glaser dan De Corte (dalam Utami, 2011) berpendapat bahwa memahami materi baru ak an menjadi sulit ketika pengetahuan awal informal dan pengetahuan awal formal yang baik pada siswa tidak digunakan dan dimanfaatkan untuk belajar materi selanjutnya.

Untuk mengatasi hal tersebut, maka guru melakukan tambahan tindakan untuk merefresh pengetahuan awal mereka melalui sistem tutor sebaya untuk mengingat kembali materi operasi perkalian dan pembagian pada bilangan. Setelah dilakukan tindakan tersebut maka terjadi peningkatan pada kemampuan pemecahan masalah pada siklus II terutama untuk indikator merencanakan dan menyelesaikan masalah sebesar $11,1 \%$ dari siklus I. Begitupun pada siklus II dan siklus III terjadi peningkatan sebesar $8,3 \%$

Berdasarkan hasil wawancara, dari 6 orang yang nilainya tidak mengalami peningk atan, diketahui 3 orang peserta didik yang belum menunjukkan peningkatan kemampuan pemecahan masalah matematika dari siklus I sampai siklus III. Hal ini disebabkan oleh latar belakang kesehatan mereka yang tidak memungkinkan untuk belajar secara normal. Hal ini tentu berdampak pula pada perolehan hasil belajar peserta didik tersebut. Melalui hasil penelitian ini, ditunjukk an pula bahwa model pembelajaran berbasis HOTs memiliki dampak positif dalam meningkatkan hasil belajar 
siswa. Hal ini dapat dilihat dari semakin bertambahnya jumlah siswa yang mencapai dan diatas KKM. Dengan demikian dapat dikatakan bahwa ketuntasan belajar siswa secara klasikal telah tercapai.

TABEL 3. Rekapitulasi Hasil Belajar Siswa

\begin{tabular}{|c|l|c|c|c|}
\hline No & \multicolumn{1}{|c|}{ Uraian } & Siklus I & Siklus II & Siklus III \\
\hline 1 & Nilai rata-rata tes formatif & 60,53 & 71,45 & 84,39 \\
2 & Jumlah siswa yang tuntas belajar & 16 orang & 25 orang & 29 orang \\
3 & Persentase ketuntasan belajar & $44,4 \%$ & $69,4 \%$ & $80,5 \%$ \\
\hline
\end{tabular}

Berdasarkan hasil tes pada siklus I, diperoleh nilai tertinggi 75 dan nilai terendah 35, Pada siklus II, diperoleh nilai tertinggi 85 dan nilai terendah 35. Pada siklus III, diperoleh nilai tertinggi $90 \mathrm{~d}$ an nilai terendah 50. Dengan demikian dapat dikatakan bahwa model pembelajaran berbasis HOTs dapat meningkatkan kemampuan pemecahan masalah peserta didik yang ditunjukkan dengan meningkatnya prosentase ketuntasan belajar secara klasikal.

\section{PENUTUP}

\section{Kesimpulan}

Model pembelajaran berbasis HOTs memiliki dampak positif dalam meningkatkan kema mpuan pemecahan masalah peserta yang ditandai dengan peningkatan ketuntasan belajar siswa dalam setiap siklus, yaitu siklus I sebesar 44,4\%, siklus II sebesar 69,4\%, dan siklus III sebesar 80,5\%. Me tode pembelajaran berbasis HOTs dapat menjadikan siswa merasa dirinya mendapat perhatian dan kesempatan untuk menyampaikan pendapat, gagasan, ide dan pertanyaan. Penerapan model pembelajaran berbasis HOTs pun memiliki pengaruh positif, yaitu dapat meningkatkan kemampu an pemecahan masalah matematika siswa sekaligus meningkatkan hasil belajar sisw a secara klasikal pada mata pelajaran matematika.

\section{REFERENSI}

Hidayati, Arini Ulfah. 2017. "Melatih Keterampilan Tingkat Tinggi Dalam Pembelajaran Matematika Pada Siswa". Jurnal Pendidikan dan Pembelajaran Dasar Volume 4 No. 2. Online. Diakses tanggal 12 Januari 2019.

Hosnan. 2014. Pendekatan Saintifik dan Kontekstual dalam Pembelajaran Abad 21. Bogor: Ghalia Indonesia. 9 Oktober 2013.

Permendikbud No. 22 Tahun 2016. Jakarta: Kementerian Pendidikan dan Kebudayaan.

Rosarina, Gina, dkk. 2016. Penerapan Model Discovery Learning Untuk Meningkatkan Hasil Belajar Siswa Pada Materi Perubahan Wujud Benda. Jurnal Pena Ilmiah Vol. 1 No.1.

Sa'ad, N.S dan Ghani, A.S. 2008. Teaching Mathematics in Secondary School Theories and Practice. Perak: Universitas Sultan Idris.

Sani, Ridwan Abdullah. 2016. Inovasi Pembelajaran. Bandung: Bumi Aksara.

Shadiq, Fadjar. 2014. Belajar Memecahkan Masalah Matematika. Yogyakarta: Graha Ilmu.

Sudjana, Nana. 2014. Dasar-Dasar Belajar Mengajar. Bandung: Remaja Rosda Karya.

Suryosubroto. 2009. Proses Belajar Mengajar di Sekolah. Jakarta: PT. Rineka Cipta

Soemarno, U dan Hendriana, H. 2014. Penilaian Pembelajaran Matematika. Bandung: Refika Aditama.

Trianto. 2010. Model Pembelajaran Terpadu. Jakarta: PT. Bumi Aksara. 
Utami, N. W. 2011. Optimalisasi Sumber Belajar Dalam Peningkatan Apresiasi Siswa Terhadap Matematika. Yogyakarta: Univeritas Negeri Yogyakarta.

Widyantini. 2014. Laporan Penelitian Pengembangan Model Pembelajaran Project Based Learning dalam Pembelajaran Matematika. Yogyakarta: PPPTK. 